\title{
Next Generation Sequencing (NGS) for the Determination of Fish Flesh Microbiota
}

\author{
Theofania Tsironi ${ }^{1}$, Vladimiros Lougovois ${ }^{2}$, Vassiliki Nefeli Simou ${ }^{2}$, Afrodite Mexi $^{2}$, Stamatios Koussissis ${ }^{2}$, \\ Efstathia Tsakali ${ }^{2,3}$, Spiridon Andreas Papatheodorou ${ }^{2}$, Valentini Stefanou ${ }^{2}$, Jan Van Impe ${ }^{3} \&$ Dimitra \\ Houhoula $^{2}$ \\ ${ }^{1}$ Laboratory of Food Chemistry and Technology, School of Chemical Engineering, National Technical University \\ of Athens, Athens, Greece \\ ${ }^{2}$ Department of Food Science and Technology, Faculty of Food Sciences, University of West Attica, Athens, \\ Greece \\ ${ }^{3}$ Department of Chemical Engineering, BioTeC+ - Chemical and Biochemical Process Technology and Control, \\ KU Leuven, Gent, Belgium \\ Correspondence: Efstathia Tsakali, BioTeC+ - Chemical and Biochemical Process Technology and Control, KU \\ Leuven, Gebroeders De Smetstraat 1, 9000 Gent, Belgium. Tel: 30-699-454-3717. E-mail: \\ efi.tsakali@kuleuven.be
}

Received: March 4, 2019

Accepted: March 29, 2019 Online Published: June 30, 2019

doi:10.5539/jfr.v8n4p101

URL: https://doi.org/10.5539/jfr.v8n4p101

\begin{abstract}
The objective of the study is the assessment of the microbial ecology and safety of fish in Greece using next-generation sequencing (NGS) and the correlation of the species of microbial flora with the production of histamine. Fourteen different fish species were obtained from local fish stores (Greece) within 1 day from capture. The initial microbiota in fish flesh was determined using NGS. The main pathogenic bacterial species identified in the tested fish samples included Vibrio spp., Clostridium spp., Staphylococcus, Flavobacterium and Janthinobacterium representing both native freshwater habitats and contaminants arising from different sources, including sewage and direct contamination by wild animals, livestock, and feed. The initial spoilage microbiota of fish consisted of several psychrotrophic Gram-negative bacteria, such as Pseudomonas, Acinetobacter, Moraxella, Shewanella, Psychrobacter, Lactobacillus, Brochothrix and Photobacterium. The results of the study show the potential of the application and the usefulness of NGS for the determination of microbial flora associated with food-borne diseases and spoilage in fish products. Histamine formation correlated with the valid reads (concentration and number of bacteria) and slightly with the genus of the identified microorganisms.
\end{abstract}

Keywords: fish, next-generation sequencing, spoilage bacteria, pathogens, 16S rRNA, histamine

\section{Introduction}

Food borne diseases are reported as an important threat for public health and the European economy. Overall, more than 250 different food borne diseases have been reported, with the majority being bacterial infections. Several bacterial illnesses might be attributed to seafood consumption that has been contaminated either at source or during processing and/or retail display. Such illness cases may be related to infection with bacteria or the ingestion of toxins having been produced in the food product prior to consumption. Along with human non-pathogenic bacteria and natural microflora relevant to the aquatic environment, pathogenic bacteria are often isolated from fish. According to the European Food Safety Authority and the literature, pathogens such as Campylobacter, Salmonella, Yersinia, E. coli, and Listeria monocytogenes are responsible for significant foodborne outbreaks globally (Leisner \& Gram, 1999; Novoslavskij et al., 2016). Fish has been reported as the most commonly implicated food category in outbreaks. Approximately 260.000 people get sick daily in the United States after consumption of contaminated fish (Barrett et al., 2015). According to FAO (2018), disease or illness outbreaks that were attributed to the consumption of fish and shellfish in the EU in the period 1983-1992 ranged between $1.9 \%$ (United Kingdom, Scotland) to $12.4 \%$ (Denmark) of total food-borne outbreaks. In the case that food source has been identified, the range of fish and shellfish outbreaks ranged between $4.4 \%$ (United Kingdom, England/Wales) to $16.1 \%$ (Finland). However, not all pathogens are connected with fish and fish product related foodborne outbreaks. 
At the same time, an increasing consumer demand for high quality fish products has been reported globally. However, fresh fish is a significantly perishable food product due to its composition and its spoilage is attributed mainly to microbial activity. Hygiene practices and temperature during handling, transportation and storage are the most important factors that determine fresh fish safety and quality up to the consumer level. Pseudomonas spp. is reported as the dominant spoilage microorganism in the case of aerobically stored fresh, chilled fish (Giuffrida et al., 2013). Pseudomonas spp. growth has also been reported as an adequate quality indicator for the determination of shelf life of Mediterranean fish during aerobic storage, such as gilthead seabream (Sparus aurata) (Tsironi \& Taoukis, 2010; Tsironi \& Taoukis, 2012 and 2014). However, changes in storage conditions, including temperature and packaging, results in significant modifications in the spoilage mechanisms and determine the dominant spoilage bacteria of the fish product. For example, the microflora of modified atmosphere packaged fish is dominated mainly by various Gram-positive microorganisms, mainly lactic acid bacteria as these microorganisms show higher resistance to $\mathrm{CO}_{2}$ (Sivertsvik et al., 2002). A codominance of lactic acid bacteria and Brochothrix thermosphacta in modified atmosphere packaged $\left(40 \% \mathrm{CO}_{2}\right)$ gilthead seabream has been reported by Drosinos et al. (1997), while Dalgaard et al. (1997) reported considerable contribution of Photobacterium phosphoreum in the spoilage of chilled modified atmosphere packaged cod, trout and tuna. Although microbial analysis of fish and fish products has been mostly implemented using conventional culture methods, recently novel molecular tools have been applied in order to most accurately evaluate the spoilage and pathogenic bacteria present in these products (Özdemir \& Arslan, 2019; Kaktcham et al., 2019) .

Consumption of seafood products, mainly scombroid fish, is associated with histamine fish poisoning (HFP). Histamine is formed in fish by the activity of microorganisms which have the ability to produce the enzyme histidine decarboxylase. The histidine decarboxylases produced by these bacteria catalyse the conversion of free histidine, naturally present at high levels in the muscle of some fish, to histamine. The species that are reported to most likely to produce histamine are Morganella morganii, Morganella psychrotolerans, Photobacterium damselae, Photobacterium phosphoreum, Raoultella planticola, Hafnia alvei and Klebsiella spp. (Dalgaard et al., 2008; EFSA, 2011; Veciana-Nogues et al., 2004). The incriminated fish in most cases contain high histamine levels, which is attributed to bacterial activity as a result of inappropriate handling, processing and/or storage conditions. In general, histamine has been implicated, at least partly, as a major causative agent. In healthy individuals HFP may be reported after the consumption of a dose of at least $50 \mathrm{mg}$ histamine by fish and fish products. If we estimate a single serving size of $250 \mathrm{~g}$ as a high consumption level, a limit of $200 \mathrm{mg} / \mathrm{kg}$ has been determined (FAO/WHO, 2013). According to the US regulations seafood is safe for consumption when histamine concentration is below $50 \mathrm{mg} / \mathrm{kg}$. The value considered in the EU is $100 \mathrm{mg} / \mathrm{kg}$. Along with the current trend to develop novel diagnostic tools for food pathogens and outbreak related toxins, rapid and cost effective methods are also developed for the evaluation of the potential of a specific fish product to be implicated to HFP. Hasan et al. (2019) developed a rapid tool for the electrochemical sensing of histamine in fish based on magnetic molecularly imprinted polymer.

Because of recent crises in food quality and safety, food monitoring is regarded as one of the top priorities of the EU-Commission. The White Paper on Food Safety reinforces the need for controls "from the farm to the fork", which includes: (i) official controls, (ii) raised food safety standards according to the microbiological criteria of the Codex Alimentarius, and (iii) improved detection methods and laboratory quality control. The introduction of NGS represents an important, fundamental technological advance in the biological sciences since the development of the polymerase chain reaction (PCR) in the mid-1980s. It has provided powerful new tools for the determination and study of non-culturable or poorly characterized organisms and emerging pathogens and it thus can enable rapid and open-ended profiling of genotypic and diagnostic markers for virulence and antimicrobial resistance (Peters et al., 2004; Diaz-Sanchez et al., 2013). Few applications on NGS have been reported recently for the determination of microbial flora in food products, i.e., dairy products (Ribani et al., 2018), fish (red drum) (Silbande et al., 2018) and shrimp (Yang et al., 2017).

The objective of the study is the assessment of the microbial ecology and safety of fish in Greece by NGS and the correlation of the species of microbial flora with the production of histamine.

\section{Materials and Methods}

\subsection{Raw Materials and Preparation of Samples}

A representative number of fish samples was obtained from local fish stores (Greece) and transported to the Department of Food Science and Technology (University of West Attica, Greece) within 2 hours. 14 different species were studied in total, i.e., (1) Atlantic salmon (Salmo salar), (2) Albacore tuna (Thunus alalunga), (3) European anchovy (Engraulis encrasicolus), (4) Chub mackerel (Scomber japonicus), (5) Atlantic mackerel 
(Scomber scombrus), (6) European pilchard (Sardina pilchardus), (7) Grey mullet (Mugil cephalus), (8) European hake (Merluccius merluccius), (9) Gilthead seabream (Sparus aurata), (10) European sea bass (Dicentrarchus labrax), (11) Picarel (Spicara smaris), (12) Comber (Serranus cabrilla), (13) Dentex (Dentex macrophthalmus) and (14) Striped red mullet (Mullus surmuletus). Samples were transported directly to the laboratory in polystyrene boxes with appropriate quantity of flaked ice $\left(0^{\circ} \mathrm{C}\right)$.

Minced fish flesh was inoculated with the reference strain Morganella morganii ATCC 25830 and placed in sterile plastic tubes at $37^{\circ} \mathrm{C}$ for $24 \mathrm{~h}$. This procedure activated the culture used as the inoculum.

Inoculated and Control samples were stored at controlled isothermal conditions of 0 and $10^{\circ} \mathrm{C}$ in high-precision $\left( \pm 0.2^{\circ} \mathrm{C}\right)$ low-temperature incubators (Sanyo MIR 153, Sanyo Electric, Ora-Gun, Gunma, Japan). Temperature in the incubators was constantly monitored with electronic, programmable miniature dataloggers (COX TRACER ( , Belmont, NC). Samples were taken at days 0,4 and 8 for microbiological analysis and determination of histamine concentration.

\subsection{DNA Extraction and Next Generation Sequencing}

Fish samples were aseptically homogenized in a laminar flow hood. DNA extraction was performed using the NucleoSpin Tissue kit (Macherey-Nagel, GmbH \& Co. KG, Germany) according to the manufacturer's instructions, with the addition of a Proteinase $\mathrm{K}$ overnight incubation step at $65^{\circ} \mathrm{C}$. Extracted DNA was quantified using a spectrophotometer at $260 \mathrm{~nm}$ and $280 \mathrm{~nm}$. After DNA extraction, 16S rRNA genes were amplified using domain-level bacterial primers that contain sequencing adapters and unique, sample-specific sequences.

Multiple samples barcoded and sequenced simultaneously on a single Ion PGM 318 chip resulted in sufficient number of reads. The number of total reads per sample was between $2.5 \times 10^{6}$ and $4.5 \times 10^{6}$. Approximately $50-65 \%$ of these reads passed stringency filters and of these, 60-75\% mapped to the databases.

The primers included in the kit are used to amplify $16 \mathrm{~S}$ variable regions from samples. After generating amplicons, the Ion Plus ${ }^{\mathrm{TM}}$ Fragment Library Kit was used to ligate barcoded adapters and synthesize libraries. Barcoded libraries from all 14 samples were pooled and templated on the OneTouch $2^{\mathrm{TM}}$ system followed by 400bp sequencing on the Ion PGM. Automated analysis, annotation and taxonomic assignment occurs via the Ion Reporter Software pipeline. Classification of reads is through alignment to either the curated MicroSEQ ID or curated Green genes databases.

\subsection{Microbiological Analysis}

For microbiological enumeration, a representative sample $(10 \mathrm{~g})$ was transferred to a sterile stomacher bag with $90 \mathrm{~mL}$ sterilized Ringer solution (Merck, Darmstadt, Germany) and was homogenized for $60 \mathrm{~s}$ with a Stomacher (BagMixer ${ }^{\circledR}$ interscience, France). Samples $(0.1 \mathrm{~mL})$ of 10 -fold serial dilutions of fish homogenates were spread on the surface of the appropriate media in Petri dishes for enumeration of different spoilage bacteria. Total aerobic viable count was enumerated on Plate Count Agar (PCA, Merck, Darmstadt, Germany) after incubation at $25^{\circ} \mathrm{C}$ for $72 \mathrm{~h}$. Pseudomonas spp. were isolated and enumerated on Cetrimide Agar (CFC, Merck, Darmstadt, Germany) after incubation at $25^{\circ} \mathrm{C}$ for $48 \mathrm{~h}$. Morganella morganii was isolated and enumerated on blood agar after incubation at $37^{\circ} \mathrm{C}$ for $24 \mathrm{~h}$. For Enterobacteriaceae spp. isolation and enumeration the pour-plate method was used, on Violet Red Bile Dextrose Agar (VRBD, Merck, Darmstadt, Germany) after incubation at $25^{\circ} \mathrm{C}$ for $48 \mathrm{~h}$.

\subsection{Evaluation of Histamine Concentration}

Veratox ${ }^{\circledR}$ for Histamine test kit (AOAC-RI \#070703 approved method, Product No. 9505, Neogen, USA) was used for the quantitative analysis of histamine in fish flesh. The test is a competitive direct ELISA. The range of quantitation was from $2.5 \mathrm{mg} / \mathrm{kg}$ to $50 \mathrm{mg} / \mathrm{kg}$.

The color intensity in the microtiter wells was measured photometrically using the Spectrostar Nano plate reader (BMG labtech, Ortenberg, Germany). The MARS Data Analysis software v.3.01 R2 (BMG labtech, Ortenberg, Germany) was used to evaluate the results.

\section{Results and Discussion}

In the present study the dominant initial microbiota of 14 fish species obtained from the Greek fish market were evaluated. 16S rRNA gene sequence analysis gave information at both species and strain levels.

The main pathogenic bacterial species identified in the tested fish samples included Vibrio spp., Clostridium spp., Staphylococcus, Flavobacterium and Janthinobacterium representing both native freshwater habitats and contaminants arising from different sources, including sewage and direct contamination by wild animals, 
livestock, and feed. The initial spoilage microbiota of fish consisted of various psychrotrophic Gram-negative bacteria, mainly Pseudomonas, Acinetobacter, Moraxella, Shewanella, Psychrobacter, Lactobacillus, Brochothrix and Photobacterium.

Several researchers have studied the spoilage microbiota of iced fish caught from the Mediterranean area by using a classical approach and concluded that Pseudomonas spp. and Shewanella spp. are the most predominant spoilage microorganisms grown on plates. The results of the present study are in agreement with previous studies investigating the initial spoilage microbial flora of fish (Gram \& Dalgaard, 2002; Koutsoumanis et al., 2002; Tsironi \& Taoukis, 2012). Psychrobacter spp., which was identified in most of the studied species, was first reported as part of the initial microbiota of fish from Greek waters by a recent study by Parlapani et al. (2015) in sea bream using 16S rRNA gene analysis. A high prevalence of Staphylococcus spp. was also observed, as also reported by Chaillou et al. (2014). Coliforms were not detected at all tested storage temperatures. The microbial load (i.e., total viable count.) in Control fish and samples inoculated with Morganella morganii during storage at 0 and $10^{\circ} \mathrm{C}$ is illustrated in Figures 1-4. It is evident that the microbial count is in all cases higher for the samples stored at $10^{\circ} \mathrm{C}$ compared to the respective samples stored at $0^{\circ} \mathrm{C}$.

Histamine concentration in Control fish and in samples contaminated with Morganella morganni, stored isothermally at 0 or $10^{\circ} \mathrm{C}$, is presented in Figure 5. Histamine levels were higher for samples stored at $10^{\circ} \mathrm{C}$ compared to the respective samples stored at $0^{\circ} \mathrm{C}$. According to FAO/WHO (2013), histamine formation in fish is dependent on the time/temperature conditions during handling, and therefore time/temperature control is an important issue from harvesting to the time of consumption. The absence or negligible production of histamine in some of the tested samples may be attributed to either a low free-histidine content in the flesh or the absence of histamine-producing bacteria such as Morganella morganii, Raoultella spp. and Photobacterium phosphoreum in the fish flesh microflora (Kanki et al., 2004; Özoğul, 2004; Silbande et al., 2018). In the European Union (EU) and Codex, fish such as Scombridae, Clupeidae, Engraulidae, Coryphaenidae, Pomatomidae and Scomberesocidae are identified as scombrotoxin hazards (FAO/WHO, 2013). Histamine formation correlated with the valid reads (indicating the concentration and number of bacteria) and slightly with the genus of the identified microorganisms, as indicated in Tables 1 and 2. The activity of Morganella morganii in the contaminated samples indicated a synergistic effect with the natural microflora for the formation of histamine during isothermal storage of fish, especially at $10^{\circ} \mathrm{C}$.

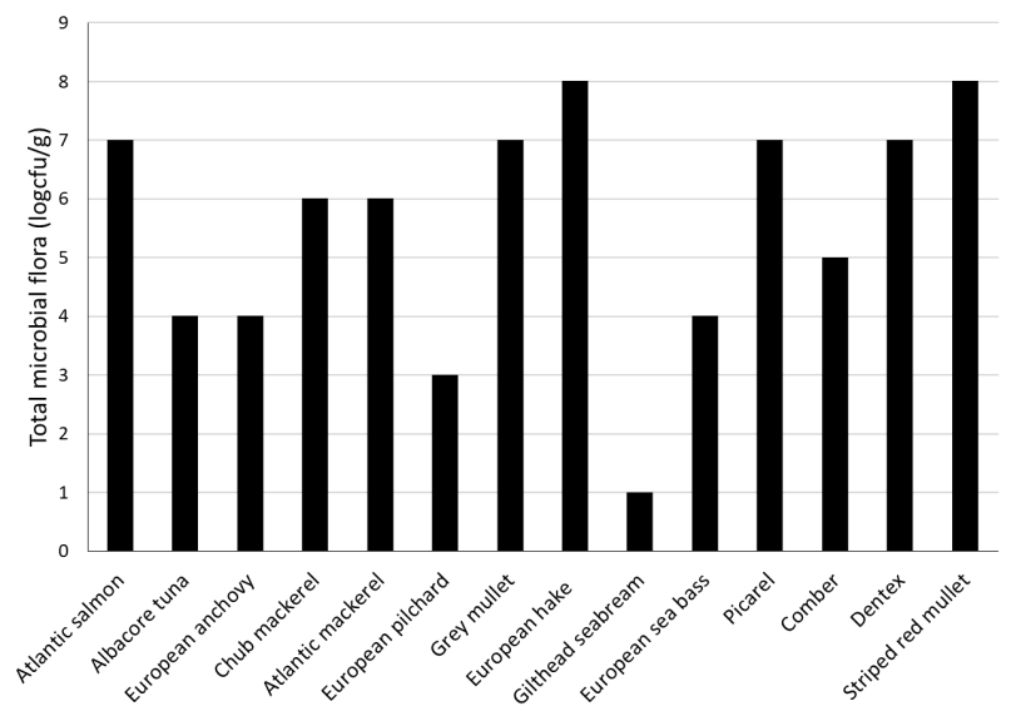

Figure 1. Mean value (log cfu/g) of total microbial flora in Control fish stored isothermally at $0^{\circ} \mathrm{C}$, for $0-8$ days, enumerated using culture techniques 


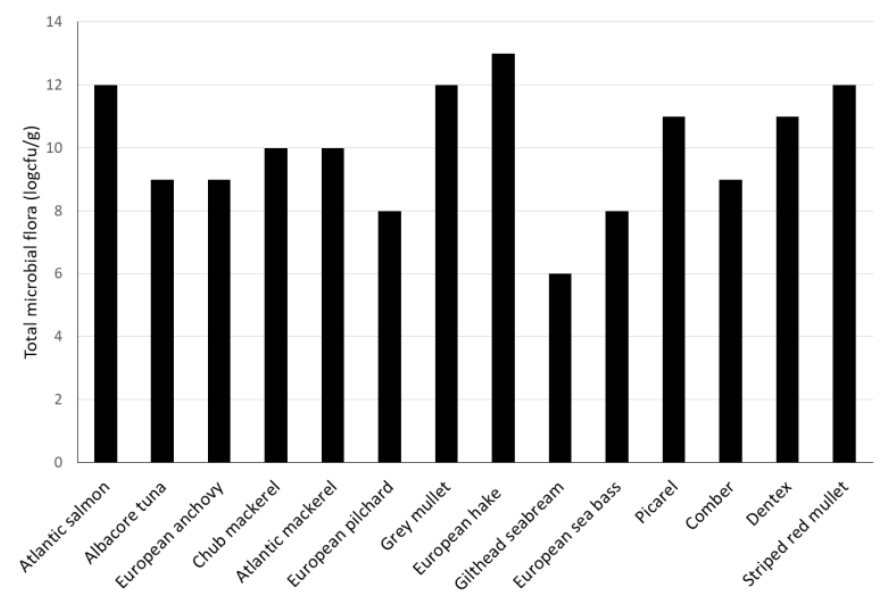

Figure 2. Mean value (log cfu/g) of total microbial flora in Control fish stored isothermally at $10^{\circ} \mathrm{C}$, for $0-8$ days enumerated using culture techniques

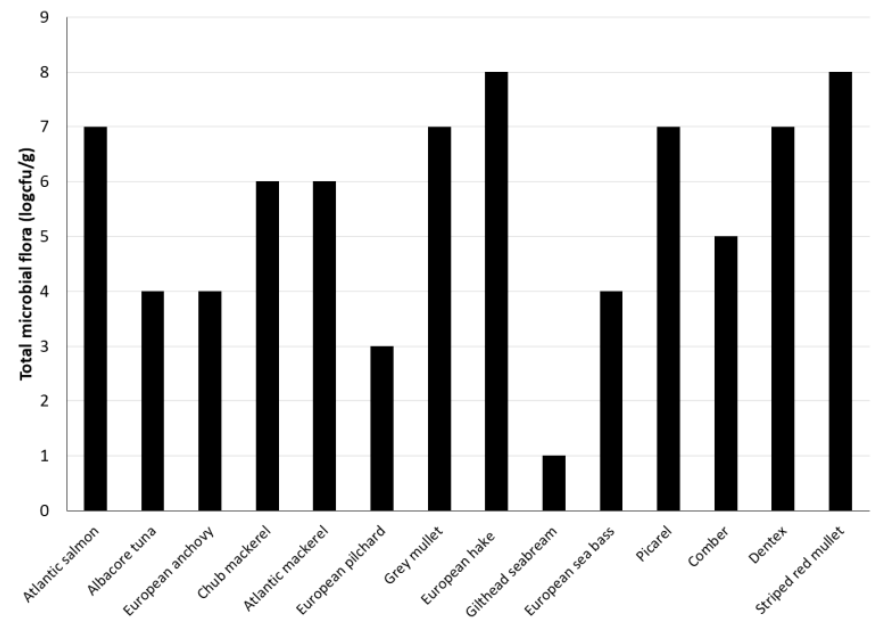

Figure 3. Mean value (log cfu/g) of total microbial flora in fish inoculated with Morganella morganii stored isothermally at $0^{\circ} \mathrm{C}$, for $0-8$ days enumerated using culture techniques

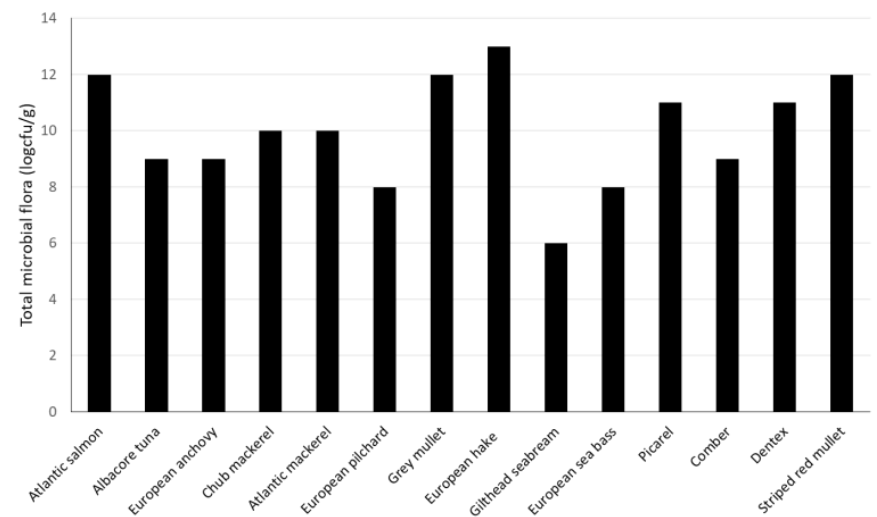

Figure 4. Mean value (log cfu/g) of microbial load in fish inoculated with Morganella morganii stored isothermally at $10^{\circ} \mathrm{C}$ for 0 to 8 days, enumerated using culture techniques 


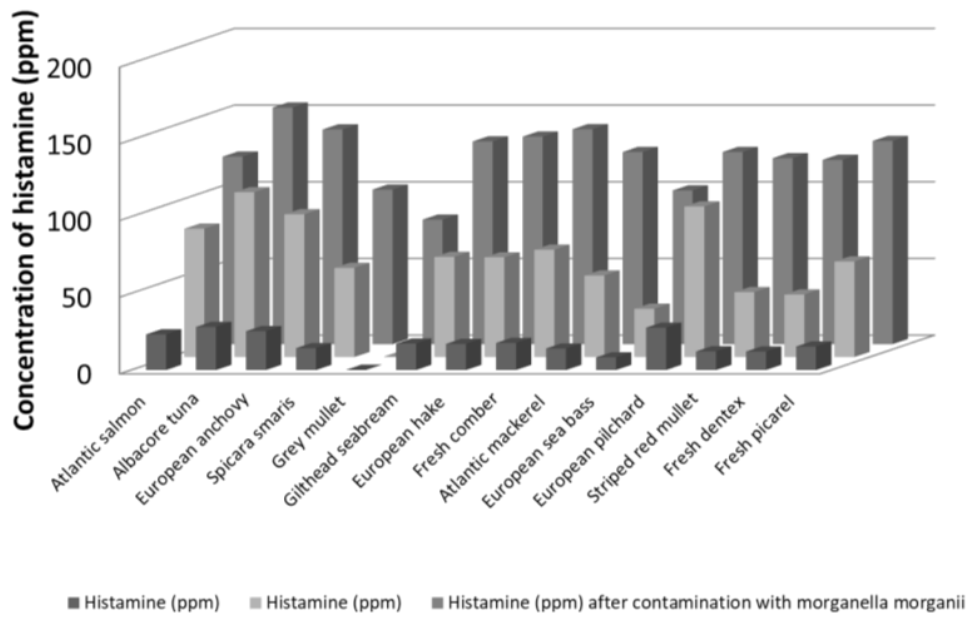

Figure 5. Concentration of histamine (ppm) in fish samples after 4 and 8 days at $10^{\circ} \mathrm{C}$

Table 1. Main Identified bacteria with NGS in different fish species correlated with the production of Histamine after 4 and 8 days at $10^{\circ} \mathrm{C}$

\begin{tabular}{|c|c|c|c|}
\hline Main Identified bacteria & Fish species & $\begin{array}{l}\text { Histamine (ppm) } \\
\mathrm{T}=10^{\circ} \mathrm{C} 4 \text { days }\end{array}$ & $\begin{array}{l}\text { Histamine (ppm) } \\
\mathrm{T}=10^{\circ} \mathrm{C} 8 \text { days }\end{array}$ \\
\hline $\begin{array}{l}\text { Blastococcus, Kosuria Propionibacterium Brochothrix streptococcus, } \\
\text { Janthinobacterium Shewanella Acinetobacter Pseudomonas }\end{array}$ & Atlantic salmon & 23,2 & 83,7 \\
\hline $\begin{array}{l}\text { Chryseobacterium, Flavobacterium Soonwooa, Sphingobacterium } \\
\text { Paracoccus, Comamonas Acinetobacter Enhydrobacter Moraxella } \\
\text { Psychrobacter Pseudomonas Stenotrophomonas Xanthomonas }\end{array}$ & Albacore tuna & 28,1 & 107,5 \\
\hline $\begin{array}{l}\text { Corynebacterium Microbacterium Propionibacterium Staphylococcus } \\
\text { Lactobacillus Streptococcus Aeromonas Shewanella Acinetobacter, } \\
\text { Enhydrobacter Psychrobacter Pseudomonas Aliivibrio Photobacterium } \\
\text { Vibrio }\end{array}$ & European anchovy & 25,3 & 93,1 \\
\hline $\begin{array}{l}\text { Chryseobacterium Acinetobacter Enhydrobacter Moraxella Pseudomonas } \\
\text { Photobacterium Vibrio }\end{array}$ & Spicara smaris & 14,2 & 58,2 \\
\hline $\begin{array}{l}\text { Propionibacterium Flavobacterium Brochothrix } \quad \text { Staphylococcus } \\
\text { Lactobacillus Streptococcus }\end{array}$ & Grey mullet & 0,1 & 0,37 \\
\hline 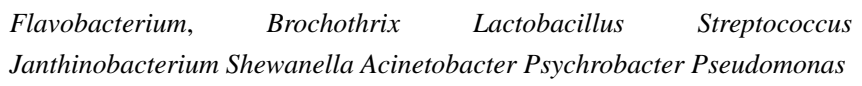 & Gilthead seabream & 4,3 & 25,3 \\
\hline $\begin{array}{l}\text { Flavobacterium Brochothrix Streptococcus Shewanella Acinetobacter } \\
\text { Psychrobacter Pseudomonas }\end{array}$ & European hake & 17 & 65 \\
\hline $\begin{array}{l}\text { Flavobacterium Janthinobacterium Shewanella Acinetobacter } \\
\text { Enhydrobacter Psychrobacter Pseudomonas Photobacterium }\end{array}$ & Fresh comber & 17,6 & 70 \\
\hline Streptococcus Acinetobacter Psychrobacter Pseudomonas Photobacterium & Atlantic mackerel & 14 & 53,2 \\
\hline Shewanella & European sea bass & 6,2 & 28,5 \\
\hline $\begin{array}{l}\text { Corynebacterium Propionibacterium Brochothrix Staphylococcus } \\
\text { Lactobacillus Lactococcus Streptococcus Aeromonas Shewanella } \\
\text { Acinetobacter Psychrobacter Pseudomonas Vibrio }\end{array}$ & European pilchard & 27,6 & 98,2 \\
\hline $\begin{array}{l}\text { Propionibacterium Flavobacterium Staphylococcus Streptococcus } \\
\text { Janthinobacterium Shewanella Acinetobacter Psychrobacter Pseudomonas }\end{array}$ & Striped red mullet & 12,1 & 42,3 \\
\hline Propionibacterium Streptococcus Acinetobacter Pseudomonas & Fresh dentex & 12,0 & 40,8 \\
\hline $\begin{array}{l}\text { Chryseobacterium Acinetobacter Enhydrobacter Moraxella Pseudomonas } \\
\text { Photobacterium Vibrio }\end{array}$ & Fresh picarel & 15,3 & 62,3 \\
\hline
\end{tabular}


Table 2. Main Identified bacteria with NGS in different fish species after the contamination with Morganella Morganii correlated with the production of Histamine after 4 and 8 days at $10^{\circ} \mathrm{C}$

\begin{tabular}{|c|c|c|}
\hline Main Identified bacteria & Fish species & $\begin{array}{l}\text { Histamine (ppm) } \\
\mathrm{T}=10^{\circ} \mathrm{C} 4 \text { days }\end{array}$ \\
\hline 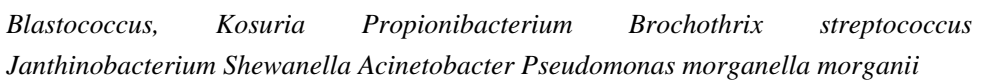 & Atlantic salmon & 122,3 \\
\hline $\begin{array}{l}\text { Chryseobacterium, Flavobacterium Soonwooa, Sphingobacterium Paracoccus, } \\
\text { Comamonas Acinetobacter Enhydrobacter Moraxella Psychrobacter Pseudomonas } \\
\text { Stenotrophomonas Xanthomonas morganella morganii }\end{array}$ & Albacore tuna & 154,3 \\
\hline $\begin{array}{l}\text { Corynebacterium Microbacterium Propionibacterium Staphylococcus Lactobacillus } \\
\text { Streptococcus Aeromonas Shewanella Acinetobacter Enhydrobacter Psychrobacter } \\
\text { Pseudomonas Aliivibrio Photobacterium Vibrio morganella morganii }\end{array}$ & European anchovy & 140 \\
\hline $\begin{array}{l}\text { Chryseobacterium Acinetobacter Enhydrobacter Moraxella Pseudomonas } \\
\text { Photobacterium Vibrio morganella morganii }\end{array}$ & Spicara smaris & 100,8 \\
\hline $\begin{array}{l}\text { Propionibacterium Flavobacterium Brochothrix Staphylococcus Lactobacillus } \\
\text { Streptococcus morganella morganii }\end{array}$ & Grey mullet & 81,2 \\
\hline $\begin{array}{l}\text { Flavobacterium , Brochothrix Lactobacillus Streptococcus Janthinobacterium } \\
\text { Shewanella Acinetobacter Psychrobacter Pseudomonas morganella morganii }\end{array}$ & Gilthead seabream & 42,1 \\
\hline $\begin{array}{l}\text { Flavobacterium Brochothrix Streptococcus Shewanella Acinetobacter Psychrobacter } \\
\text { Pseudomonas morganella morganii }\end{array}$ & European hake & 135,3 \\
\hline $\begin{array}{l}\text { Flavobacterium Janthinobacterium Shewanella Acinetobacter Enhydrobacter } \\
\text { Psychrobacter Pseudomonas Photobacterium morganella morganii }\end{array}$ & Fresh comber & 140,2 \\
\hline $\begin{array}{l}\text { Streptococcus Acinetobacter Psychrobacter Pseudomonas Photobacterium } \\
\text { morganellamorganii }\end{array}$ & Atlantic mackerel & 125,3 \\
\hline Shewanella morganella morganii & European sea bass & 40,2 \\
\hline $\begin{array}{l}\text { Corynebacterium Propionibacterium Brochothrix Staphylococcus Lactobacillus } \\
\text { Lactococcus Streptococcus Aeromonas Shewanella Acinetobacter Psychrobacter } \\
\text { Pseudomonas Vibrio morganella morganii }\end{array}$ & European pilchard & 125,3 \\
\hline $\begin{array}{l}\text { Propionibacterium Flavobacterium Staphylococcus Streptococcus Janthinobacterium } \\
\text { Shewanella Acinetobacter Psychrobacter Pseudomonas morganella morganii }\end{array}$ & Striped red mullet & 121,3 \\
\hline Propionibacterium Streptococcus Acinetobacter Pseudomonas morganella morganii & Fresh dentex & 120,2 \\
\hline $\begin{array}{l}\text { Chryseobacterium Acinetobacter Enhydrobacter Moraxella Pseudomonas } \\
\text { Photobacterium Vibrio morganella morganii }\end{array}$ & Fresh picarel & 132,5 \\
\hline
\end{tabular}

\section{Conclusions}

The objective of the study was the assessment of the microbial ecology and safety of fish in Greece using NGS and the correlation of the species of microbial flora with the production of histamine. Fourteen different fish species were obtained from local fish stores (Greece) within 1 day from capture. Using a Next Generation Sequencing approach, a rapid and sensitive method for the identification of bacterial species in polymicrobial samples was demonstrated. The main pathogenic bacterial species identified in the tested fish samples included Vibrio spp., Clostridium spp., Staphylococcus, Flavobacterium and Janthinobacterium, which represent native freshwater habitats and contaminants arising from sources such as sewage, wild animals, livestock, and feed. The initial spoilage microbiota of fish consisted of several psychrotrophic Gram-negative bacteria, mainly Pseudomonas, Acinetobacter, Moraxella, Shewanella, Psychrobacter, Lactobacillus, Brochothrix and Photobacterium. The results of the study show the potential of the application and the usefulness of NGS for the determination of microbial flora associated with food-borne diseases and spoilage in fish products. Histamine concentration in Control fish and in samples inoculated with Morganella morganni and stored isothermally at 0 or $10^{\circ} \mathrm{C}$ was evaluated after 4 and 8 days. In general, histamine concentration reached higher values in fish stored at $10^{\circ} \mathrm{C}$ compared to iced storage. Low concentrations of histamine in some fish species was attributed to either a low free-histidine level in the fish flesh of low microbial counts referring to microorganisms such as Morganella morganii, Raoultella spp. and Photobacterium phosphoreum (for Control fish samples). Histamine formation correlated with the valid reads (concentration and number of bacteria) and slightly with the genus of the identified microorganisms. The activity of Morganella morganii in the contaminated samples indicated a synergistic effect with the natural microflora for the formation of histamine during isothermal storage of fish, especially at $10^{\circ} \mathrm{C}$. 
It is necessary to study the prevalence of bacteria in fish to ensure a better understanding of ecology and distribution of pathogens and spoilage microorganisms in the food chain. The determination of fish microbiota is currently carried out mainly by phenotypic tests (morphological, biochemical) after the isolation of microorganisms using various non-selective and/or selective growth media. The application of novel molecular tools and "omics" techniques in food safety and quality has the potential to answer questions which conventional microbiological methods are not able to address. In the present study, the application of NGS for the microbial assessment of chilled fish is introduced. In general, Good Hygienic Practices are a measure to prevent fish contamination during handling, distribution and storage and to provide safe, high quality fish and fish products. The conventional methods for determination of microbial flora in food products have been proven to detect species when the potential bacteria are already defined or expected in advance as the discriminatory analytical methods for their identification have to be specifically tailored. On the other hand, NGS technologies have improved DNA analysis methods by combining sequencing and quantification of DNA in a single step. By using universal primers to amplify several regions, it is possible to obtain an internal validation of the results derived by the concordance of the assigned reads to a species. Technological developments in the field of microbiology, such as NGS techniques and the omics approach in general, have significantly enhanced our understanding of the behaviour of microorganisms and particularly their physiological state. The perishability of fish and fish products results in their limited shelf life, especially considering the temperature fluctuations that occur in the actual food cold chain which affect significantly the safety and quality level of these products at the time of consumption. The quality and shelf life of fish can be improved if the spoilage mechanism of these products is well defined and clearly understood. The spoilage potential of some members of the fish microbiota is not yet investigated or characterized. The detection of non-cultivable bacteria in fish products remains a challenge, as thee microorganisms may play a significant role in the safety and spoilage process of fish. These innovative approaches could reveal patterns of responses that cannot be detected by classical methods and have the potential to ultimately uncover new and powerful methods to control hazards in food and feed. This may potentially bring more insight than just the usual 'snapshot' in the farm-to-fork contamination process analysis and therefore contribute to the next generation of risk assessment (den Besten et al., 2018). Under this context, the present study might be a baseline for further investigation of the pathogenic and spoilage potential of the identified microorganisms present in Greek (and consequently Mediterranean) fish products. The identified microorganisms should be further studied for their potential corellation with physical, chemical and sensory quality indices changes during storage at simulated (isothermal) conditions and in the real chill chain (variable temperature conditions). A similar approach may be expanded to other food products, such a meat, dairy etc., where the definition of the microbiota is of significant importance.

\section{Acknowledgement}

This study was supported by the IKY FELLOWSHIPS OF EXCELLENCE FOR POSTGRADUATE STUDIES IN GREECE - SIEMENS PROGRAM: "Next generation sequencing for the diagnosis of pathogenic bacteria in Greek fisheries: A novel technique, common to face major public health issues" (Thematic area: Health, Field: Biotechnology-Molecular biotechnology, 2016-2017), by Fund for Scientific Research FWO-Vlaanderen (grant G.0863.18) and by the KU Leuven Research Fund (Center of Excellence OPTEC-Optimization in Engineering and project C24/18/046).

Special thanks to Prof. Petros Taoukis for providing the infrastructure necessary for the determination of histamine concentration in the Laboratory of Food Chemistry and Technology, School of Chemical Engineering, National Technical University of Athens.

\section{References}

Barrett, K. A., Nakao, J. H., Eggers, C., \& Gould, L. H. (2015). Fish-associated foodborne disease outbreaks: United States, 1998-2015. Foodborne Pathogens and Disease, 14(9), 537-543. https://doi.org/10.1089/fpd.2017.2286

Chaillou, S., Chaulot-Talmon, A., Caekebeke, H., Cardinal, M., Christiaens, S., Denis, C., Desmonts, M. H., ... Champomier-Vergès, M. C. (2014). Origin and ecological selection of core and food-specific bacterial communities associated with meat and seafood spoilage. International Society for Microbial Ecology, 1(14), 1751-7362.

Dalgaard, P., Emborg, J., Kjølby, A., Sørensen, N. D., \& Ballin, N. Z. (2008). Histamine and biogenic amines: formation and importance in seafood. In T. Børresen (Eds.), Improving seafood products for the consumer (pp. 292-324). Cambridge, British Welding Research Association.

https://doi.org/10.1533/9781845694586.3.292 
Dalgaard, P., Mejlholm, O., Christiansesn, T. J., \& Huss, H. H. (1997). Importance of Photobacterium phosphoreum in relation to spoilage of modified atmosphere-packed fish products. Letters in Applied Microbiology, 24, 373-378. https://doi.org/10.1046/j.1472-765X.1997.00152.x

Den Besten, H. M. W., Amézquita, A., Bover-Cid, S., Dagnas, S., Ellouze, M., Guillou, S., ... Membré, J. M. (2018). Next generation of microbiological risk assessment: Potential of omics data for exposure assessment. International Journal of Food Microbiology, 287, 18-27. https://doi.org/10.1016/j.ijfoodmicro.2017.10.006

Diaz-Sanchez, S., Hanning, I., Pendleton, S., \& D’Souza, D. (2013). Next-generation sequencing: The future of molecular genetics in poultry production and food safety. Poultry Science, 92(2), 562-572. https://doi.org/10.3382/ps.2012-02741

Drosinos, E. H., Lambropoulou, K., Mitre, E., \& Nychas, G. J. E. (1997). Attributes if fresh gilt-head seabream (Sparus aurata) fillets treated with potassium sorbate, sodium gluconate and stored under modified atmosphere at $0 \pm 1{ }^{\circ}$ C. Journal of Applied Microbiology, 83, 569-575.

https://doi.org/10.1046/j.1365-2672.1997.00267.x

EFSA [European Food Safety Authority]. (2011). Scientific opinion on risk based control of biogenic amine formation in fermented foods. Panel on Biological Hazards (BIOHAZ). EFSA J., 9(10), 2393-2487. https://doi.org/10.2903/j.efsa.2011.2393

FAO (2018). Seafood-borne disease and illness. Retrieved from http://www.fao.org/docrep/003/x0465e/x0465e04.htm

FAO/WHO [Food and Agriculture Organization of the United Nations \& World Health Organization]. (2013). Joint FAO/WHO expert meeting on the public health risks of histamine and other biogenic amines from fish and fishery products: meeting report. World Health Organization. Retrieved from http://www.who.int/iris/handle/10665/89216

Giuffrida, A., Valenti, D., Giarratana, F., Ziino, G., \& Panebianco, A. (2013). A new approach to modelling the shelf life of gilthead seabream (Sparus aurata). International Journal of Food Science and Technology, 48(6), 1235-1242. https://doi.org/10.1111/ijfs. 12082

Gram, L., \& Dalgaard, P. (2002). Fish spoilage bacteria: problems and solutions. Current Opinion in Biotechnology, 13, 262-266. https://doi.org/10.1016/S0958-1669(02)00309-9

Hassan, A. H. A., Sappia, L., Moura, S. L., Ali, F. H. M., Moselhy, W. A., Sotomayor, M. P. T., \& Pividori, M. I. (2019). Biometric magnetic sensor for electrochemical determination of scombrotoxin in fish. Talanta, 997-1004. https://doi.org/10.1016/j.talanta.2018.10.066

Kaktcham, P. M., Foko, K. E. M., Tchabou, T. M. L., Temgoua, J.-B., Wacher, C., Zambou, N. F., \& Pérez-Chabela, M. D. L. (2019). Nisin-producing Lactococcus lactis subsp. lactis 2MT isolated from freshwater Nile tilapia in Cameroon: Bacteriocin screening, characterization, and optimization in a low-cost medium. $L W T, 107,272-279$. https://doi.org/10.1016/j.lwt.2019.03.007

Kanki, M., Yoda, T., Ishibashi, M., \& Tsukamoto, T. (2004). Photobacterium phosphoreum caused a histamine fish poisoning incident. International Journal of Food Microbiology, 92, 79-87. https://doi.org/10.1016/j.ijfoodmicro.2003.08.019

Koutsoumanis, K. P., Taoukis, P. S., Drosinos, E. H., \& Nychas, G.-J. E. (2000). Applicability of an Arrhenius model for the combined effect of temperature and $\mathrm{CO}_{2}$ packaging on the spoilage microflora of fish. Applied and Environmental Microbiology, 66, 3528-3534.

https://doi.org/10.1128/AEM.66.8.3528-3534.2000

Leisner, J. J., \& Gram, L. (1999). Spoilage of fish, in: Encyclopedia of Food Microbiology, ed. by Robinson RK, Batt CA and Patel PD. Academic Press, San Diego, CA, pp. 813-820. https://doi.org/10.1006/rwfm.1999.1845

Novoslavskij, A., Terentjeva, M., Eizenberga, I., Valciņa, O., Bartkevičs, V., \& Bērziņš, A. (2016). Major foodborne pathogens in fish and fish products: a review. Annals of Microbiology, 66(1), 1-15. https://doi.org/10.1007/s13213-015-1102-5

Özdemir, F., \& Arslan, S. (2019). Molecular Characterization and Toxin Profiles of Bacillus spp. Isolated from Retail Fish and Ground Beef. Journal of Food Science, 84(3), 548-556.

https://doi.org/10.1111/1750-3841.14445 
Parlapani, F. F., Kormas, K. A., \& Boziaris, I. S. (2015). Microbiological changes, shelf life and identification of initial and spoilage microbiota of sea bream fillets stored under various conditions using 16S rRNA gene analysis. Journal of the Science of Food and Agriculture, 95, 2386-2394. https://doi.org/10.1002/jsfa.6957

Peters, R. P., van Agtmael, M. A., Danner, S. A., Savelkoul, P. H., \& Vandenbroucke-Grauls, C. M. (2004). New developments in the diagnosis of bloodstream infections. Lancet Infect Dis, 4(12), 751-760. https://doi.org/10.1016/S1473-3099(04)01205-8

Ribani, A., Schiavo, G., Utzeri, J. U., Bertolini, F., Geraci, C., Bovo, S., \& Fontanesi, L. (2018). Application of next generation semiconductor based sequencing for species identification in dairy products. Food Chemistry, 246, 90-98. https://doi.org/10.1016/j.foodchem.2017.11.006

Silbande, A., Adenet, S., Chopin, C., Cornet, J., Smith-Ravin, J., Rochefort, K., \& Leroi, F. (2018). Effect of vacuum and modified atmosphere packaging on the microbiological, chemical and sensory properties of tropical red drum (Sciaenops ocellatus) fillets stored at $4^{\circ}$ C. International Journal of Food Micobiology, 266, 31-41. https://doi.org/10.1016/j.ijfoodmicro.2017.10.015

Silbande, A., Adenet, S., Chopin, C., Cornet, J., Smith-Ravin, J., Rochefort, K., \& Leroi, F. (2018). Effect of vacuum and modified atmosphere packaging on the microbiological, chemical and sensory properties of tropical red drum (Sciaenops ocellatus) fillets stored at $4^{\circ}$ C. International Journal of Food Microbiology, 266, 31-41. https://doi.org/10.1016/j.ijfoodmicro.2017.10.015

Sivertsvik, M., Jeksrud, W. K., \& Rosnes, J. T. (2002). A review of modified atmosphere packaging of fish and fishery products-significance of microbial growth, activities and safety. International Journal of Food Science and Technology, 37, 107-127. https://doi.org/10.1046/j.1365-2621.2002.00548.x

Tsironi, T. N., \& Taoukis, P. S. (2012). Shelf life extension of gilthead seabream fillets by osmotic treatment and antimicrobial agents. Journal of Applied Microbiology, 112, 316-328. https://doi.org/10.1111/j.1365-2672.2011.05207.x

Tsironi, T. N., \& Taoukis, P. S. (2014). Effect of processing parameters on water activity and shelf life of osmotically dehydrated fish fillets. Journal of Food Engineering, 123, 188-192. https://doi.org/10.1016/j.jfoodeng.2013.09.020

Tsironi, T., \& Taoukis, P. S. (2010). Modeling microbial spoilage and quality of gilthead seabream fillets: Combined effect of osmotic pre-treatment, modified atmosphere packaging and nisin on shelf life. Journal of Food Science, 75(4), 243-251. https://doi.org/10.1111/j.1750-3841.2010.01574.x

Veciana-Nogués, M. T., Bover-Cid, S., Mariné-Font, A., \& Vidal-Carou, M. C. (2004). Biogenic amine production by Morganella morganii and Klebsiella oxytoca in tuna. European Food Research and Technology, 218(3), 284-288. https://doi.org/10.1007/s00217-003-0860-7

Yang, S. P., Xie, J., \& Qian, Y. F. (2017). Determination of spoilage microbiota of Pacific white shrimp during ambient and cold storage using Next-Generation Sequencing and culture-dependent method. Journal of Food Science, 82(5), 1178-1183. https://doi.org/10.1111/1750-3841.13705

\section{Copyrights}

Copyright for this article is retained by the author(s), with first publication rights granted to the journal.

This is an open-access article distributed under the terms and conditions of the Creative Commons Attribution license (http://creativecommons.org/licenses/by/4.0/). 